Check for updates

Cite this: RSC Adv., 2018, 8, 25112

Received 24th May 2018

Accepted 10th June 2018

DOI: $10.1039 / \mathrm{c} 8 \mathrm{ra04438d}$

rsc.li/rsc-advances

\title{
Bio-sourced phosphoprotein-based synthesis of silver-doped macroporous zinc phosphates and their antibacterial properties $\uparrow$
}

\author{
Jessica Viviana Hinostroza Ramos, ${ }^{\text {ab }}$ Karine Anselme, ${ }^{\text {ab }}$ Angélique Simon- \\ Masseron $^{\star a b}$ and Lydie Ploux ${ }^{\mathrm{ab}}$
}

\begin{abstract}
The usual sources of phosphorus for metal phosphates are obtained from phosphate rocks, of which resources are depleted. As a substitute for these mineral sources, an original method of synthesis has been developed to prepare macroporous zinc phosphates using casein phosphoprotein. This biosourced reactant plays during the synthesis the roles of both a phosphorus source and a reducing agent for silver nanoparticles. Thus, zinc phosphates loaded with different Ag contents (up to 6.4 wt\%) are prepared via hydrothermal treatment at $100{ }^{\circ} \mathrm{C}$. Silver nanoparticles co-crystallized with hopeite, $\mathrm{Zn}_{3}\left(\mathrm{PO}_{4}\right)_{2}$ and/or $\mathrm{Zn}_{2} \mathrm{P}_{2} \mathrm{O}_{7}$. In addition, casein induces porosity within the zinc phosphate framework and provides macropores (diameter of $>50 \mathrm{~nm}$ ) during calcination. The antibacterial properties against Escherichia coli $\mathrm{K} 12$ bacteria of $\mathrm{Ag}$-containing and $\mathrm{Ag}$-free porous zinc phosphates (calcined at $750{ }^{\circ} \mathrm{C}$ ) were also tested for the first time.
\end{abstract}

\section{Introduction}

Metal phosphates have received much attention because of their versatile applications, mainly as catalysts, molecular sieves, optical materials and anticorrosive pigments. ${ }^{1-3}$ Among these materials, zinc phosphates (amorphous phases, hopeite) have also been shown to be interesting materials in dentistry applications as luting cements owing to their strong adhesion, biocompatibility and low solubility in aqueous and biological environments. ${ }^{4,5}$ In this context, the antibacterial properties of freshly prepared zinc phosphate cements have been demonstrated against Streptococcus mutans bacteria. ${ }^{6-9}$ These were attributed to the release of zinc and were greatly reduced after the cement hardened. ${ }^{10-12}$ Moreover, materials based on zinccalcium phosphates have been shown to promote bone regeneration in medical applications thanks to the essential function of zinc in bone tissue development. ${ }^{6,7,13}$ However, to the best of our knowledge, no study of environmental applications of porous zinc phosphates has been reported, yet zinc is an element with low toxicity to humans and the environment in comparison with other metals found in metal phosphates. ${ }^{11}$ They also have interesting properties for corrosion prevention. ${ }^{12-14}$ Both features are assets for use in the fields of biomedicine and water treatment.

${ }^{a}$ Université de Haute-Alsace, CNRS, IS2M UMR 7361, F-68100 Mulhouse, France. E-mail: angelique.simon-masseron@uha.fr

${ }^{b}$ Université de Strasbourg, France

$\dagger$ Electronic supplementary information (ESI) available. See DOI: $10.1039 / \mathrm{c} 8 \mathrm{ra} 04438 \mathrm{~d}$
Phosphorus sources for the synthesis of these materials are derived from phosphate rock resources, principally sedimentary marine phosphorites..$^{15}$ Approximately $82 \%$ of these phosphate rocks are exploited for the preparation of fertilizer, a few per cent for animal feed, and the rest for industrial purposes.. ${ }^{16,17}$ Because of the importance of phosphorus and the constant demand for it, the level of exploitation of phosphate rocks would reach a peak in 2033 and 2034. ${ }^{17}$ Total resource exhaustion at the current rate of world consumption is expected to occur in a few hundred years. ${ }^{15,17}$ Orthophosphoric acid is the main product of the treatment of phosphate rocks. It is also the main phosphorus source used for the synthesis of metal phosphates. ${ }^{18}$ Hence, the depletion of stocks of phosphate rocks will have a direct impact on the supply of metal phosphates. Therefore, the development of bio-sourced syntheses of metal phosphates is particularly relevant.

The development of silver-supported solids, including metal phosphates, is of constant interest for biomedical and environmental applications owing to the antimicrobial activity of $\mathrm{Ag}^{+}$ions against different Gram-positive and Gram-negative strains of bacteria. ${ }^{8,9,19}$ The bactericidal activity of $\mathrm{Ag}^{+}$ions is attributed to a combination of different biocidal actions that lead to the death of bacteria, which include degradation of the bacterial cell wall by the interaction of $\mathrm{Ag}^{+}$ions with the membrane and inactivation of protein synthesis and DNA replication..$^{8,9,20,21}$ For this purpose, the incorporation of Ag nanoparticles into materials is an efficient method of providing antibacterial properties in an aqueous medium by allowing the release of $\mathrm{Ag}^{+}$ions from oxidized $\mathrm{Ag}$ nanoparticles. When applied to porous zinc phosphates, doping with $\mathrm{Ag}$ 
nanoparticles may significantly improve the antibacterial properties of the final material. In addition, porosity may bring added value by enhancing the retention of bacteria for their further degradation.

Furthermore, the use of inorganic matrices as supports for $\mathrm{Ag}$ nanoparticles has attracted interest because of their advantages in terms of stability, heat resistance and safety in comparison with organic compounds. Studies have shown that inorganic structures such as zeolites, zinc oxide, titanium dioxide, phosphates, ceramics and glass are suitable carriers for the release of $\mathrm{Ag}^{+}$ions. ${ }^{2-25}$ In this context, several studies of the synthesis of metal phosphate materials loaded with Ag nanoparticles, which mainly focused on hydroxyapatite (calcium phosphate), have been reported. The incorporation of $\mathrm{Ag}$ nanoparticles into hydroxyapatite coatings has shown good results in the prevention of implant-associated bacterial infections, which is attractive in medical applications owing to the biocompatible properties of hydroxyapatite. ${ }^{26-28}$ Environmental applications of hydroxyapatite have also been reported. An example is the development of a filter material composed of porous hydroxyapatite loaded with $\mathrm{Ag}$ nanoparticles ${ }^{29}$ as a substitute for the typical zeolite/Ag, sand/Ag, fiberglass/Ag and resin/Ag filters used in water disinfection. ${ }^{30-33}$

Porosity in metal phosphate materials is usually generated by organic molecules such as quaternary ammonium compounds or amines, of which the supply depends on oil resources. They are usually highly toxic and environmentally unfriendly. The use of new templates obtained from new raw materials represents one of the major challenges in the synthesis of porous solids. Few studies of the synthesis of biosourced porous and nonporous metal phosphates are available in the literature, except for the synthesis of calcium phosphate. ${ }^{34-36}$ Bio-sourced zinc phosphates were reported for the first time in a recent work published by our group. ${ }^{37}$ The present paper describes the first synthesis of bio-sourced porous zinc phosphates loaded with $\mathrm{Ag}$ nanoparticles with a study of their antibacterial properties. Casein phosphoprotein (CN) from bovine milk is used. It is composed of four principal types of caseins (i.e., $\alpha_{\mathrm{s}^{-}}, \alpha_{\mathrm{s}_{2}}, \beta-$ and $\kappa$-casein), in which phosphorus is present as colloidal calcium phosphate (CCP) (inorganic phosphorus) and phosphoserine residues (SerP) (organic phosphorus). These are in the form of dispersed spherical colloidal particles known as micelles (diameter: 50$500 \mathrm{~nm}$, average: $150 \mathrm{~nm}) .^{38}$ Casein plays the role of a phosphorus source, generates porosity and permits the in situ synthesis of $\mathrm{Ag}$ nanoparticles without the use of any additional reducing agents such as commonly used hydrazine and sodium borohydride. ${ }^{39,40}$ We especially studied the influence of the calcination conditions on the composition of crystalline zinc phosphate phases (ZnPOs) prepared by this method, the sizes of $\mathrm{Ag}$ nanoparticles and textural properties. The solids were characterized by X-ray diffraction, scanning electron microscopy, transmission electron microscopy, energy-dispersive X-ray spectroscopy, thermal analysis, nitrogen adsorption and inductively coupled plasma atomic emission spectroscopy.

The antibacterial properties of zinc phosphates loaded or not loaded with Ag nanoparticles were investigated. A strain of
Escherichia coli (E. coli) K12 was chosen as a model microorganism owing to its common use as an indicator of microbial water contamination. ${ }^{41} \mathrm{E}$. coli is also frequently involved in common bacterial infections related to water such as traveler's diarrhea. ${ }^{42}$ Short-term colonization and proliferation on zinc phosphate surfaces were analyzed using confocal fluorescence microscopy. These were related to the concentrations of $\mathrm{Ag}^{+}$and $\mathrm{Zn}^{2+}$ ions released from samples of the material, which were determined by inductively coupled plasma atomic emission spectroscopy.

\section{Experimental section}

\subsection{Preparation of zinc phosphates}

A casein dispersion was prepared by adding $9.50 \mathrm{~g}(0.71 \mathrm{wt} \%$ of P) of casein powder from bovine milk (Sigma-Aldrich, technical grade) to $190 \mathrm{~mL}$ of a $3.0 \mathrm{mmol} \mathrm{L}^{-1}$ aqueous solution of sodium hydroxide ( $\mathrm{pH}$ 11.5) ( $\mathrm{NaOH}$ pellets, Sigma-Aldrich, $\geq 97 \%$ ) under magnetic stirring for $30 \mathrm{~min}$. A $0.12 \mathrm{~mol} \mathrm{~L}^{-1}$ aqueous solution of silver nitrate $\left(\mathrm{AgNO}_{3}\right.$, Sigma-Aldrich, $\left.\geq 99 \%\right)$ was then added to the casein dispersion under stirring for $20 \mathrm{~min}$ at room temperature. Then, $32 \mathrm{~mL}$ of a $0.35 \mathrm{~mol} \mathrm{~L}^{-1}$ aqueous solution of zinc nitrate $\left(\mathrm{Zn}\left(\mathrm{NO}_{3}\right)_{2} \cdot 6 \mathrm{H}_{2} \mathrm{O}\right.$, Alfa Aesar, $\left.\geq 99 \%\right)$ was added to the prepared casein/silver ion dispersion, and finally the entire reaction mixture was maintained under magnetic stirring for $20 \mathrm{~min}$ at room temperature. The resulting solution was transferred to a $500 \mathrm{~mL}$ polypropylene flask and stored at $100{ }^{\circ} \mathrm{C}$. After heating for 6 days, the product was filtered off, washed with distilled water and dried at $70{ }^{\circ} \mathrm{C}$ overnight. All chemicals and reagents were used as received without further purification.

2.1.1. Calcination conditions. The as-synthesized samples were calcined in a muffle furnace at different temperatures ranging from $250{ }^{\circ} \mathrm{C}$ to $750{ }^{\circ} \mathrm{C}$ using a heating rate of $5{ }^{\circ} \mathrm{C} \min ^{-1}$. They were cooled to room temperature $\left(20 \pm 5{ }^{\circ} \mathrm{C}\right)$ before analysis. The samples were named as ZnPOs/Ag-250, ZnPOs/Ag-500, ZnPOs/Ag-600 and ZnPOs/Ag-750 for the calcined samples that contained silver and ZnPOs-250, ZnPOs500, ZnPOs-600 and ZnPOs-750 for the calcined samples without silver (reference samples).

2.1.2. Structural and textural characterizations of zinc phosphates. The crystallinity of the samples was characterized by powder X-ray diffraction (XRD). The XRD patterns of the assynthesized samples and calcined samples were recorded using PANalytical X'Pert and STOE STADI P diffractometers, respectively. These were operated with $\mathrm{Cu} \mathrm{K} \alpha$ radiation $(\lambda=1.5406 \AA)$ for $2 \theta$ values of $3-70^{\circ}$ with steps of 0.02 or $0.28^{\circ} \mathrm{s}^{-1}$ at room temperature. X'Pert HighScore software was used to identify the crystalline phases present in the samples by comparison of the experimental diffraction patterns with reference patterns provided by the International Center for Diffraction Data (ICDD) (i.e., PDF-4+ powder diffraction files). ${ }^{43}$ The compositions of the samples were determined by inductively coupled plasma atomic emission spectrometry (ICP-AES). The morphology of the samples was determined by scanning electron microscopy (SEM) using a Philips XL30 microscope under a vacuum of $10^{-5}$ mbar. Samples were dispersed on a support 
covered with a graphite conductive tab and then coated with a thin film of gold (10 nm to $20 \mathrm{~nm}$, deposited using a Bal-Tec SCD 004 sputter coater). Micrographs were obtained with an accelerating voltage of $7 \mathrm{kV}$ at several magnifications. The sizes of silver nanoparticles were determined by transmission electron microscopy (TEM) with a JEOL ARM200 microscope operating at $200 \mathrm{kV}$. TEM images were analyzed using Image ${ }^{\circledR} 1.50 \mathrm{~b}$ software $^{\mathbf{4 4}}$ to calculate the average size of the silver nanoparticles and the standard deviation from 10 images taken of each sample. EDX mapping was performed using a Centurio JED-2300 1sr detector coupled to a TEM microscope. Thermogravimetric (TGA) and differential thermal (DTA) analyses were performed with a Setaram Labsys thermoanalyser. A sample of about $10 \mathrm{mg}$ contained in an alumina crucible was placed in a heating chamber. Measurements were recorded under an air stream with a heating rate of $5{ }^{\circ} \mathrm{C} \min ^{-1}$ up to $900{ }^{\circ} \mathrm{C}$. The presence of micro- and mesopores in the calcined samples was determined by nitrogen adsorption analysis at the boiling point of liquid nitrogen using a Micromeritics ASAP 2020 analyzer. The samples were previously degassed at $150{ }^{\circ} \mathrm{C}$ for $15 \mathrm{~h}$ in a vacuum. The specific surface area $\left(S_{\mathrm{BET}}\right)$ was determined by the BET (Brunauer, Emmett and Teller) multipoint method in the relative pressure $\left(p / p_{0}\right)$ range of 0.05 to 0.30 . To determine the macroporosity of the samples, the mercury intrusion porosimetry technique (Autopore IV, Micromeritics, USA) was selected. This is based on the progressive intrusion of mercury into the pores of a material under controlled pressure. ${ }^{\mathbf{4 4}}$ About $30 \mathrm{mg}$ of powder was introduced into the penetrometer.

\subsection{Characterization of antibacterial properties induced by the release of silver}

2.2.1. Bacterial strain and culture medium. Experiments were performed with the E. coli K12 SCC1 strain, ${ }^{45}$ which emits fluorescence at $508 \mathrm{~nm}$ under excitation at an appropriate wavelength $(396 \mathrm{~nm})$ thanks to the chromosomal insertion of GFP (green fluorescent protein). ${ }^{46}$ Bacteria were stored in a freezer at $-80{ }^{\circ} \mathrm{C}$. M63G nutrient medium ${ }^{47}$ (0.1 $\mathrm{M} \mathrm{KH}_{2} \mathrm{PO}_{4}$, $20 \mathrm{wt} \%\left(\mathrm{NH}_{4}\right)_{2} \mathrm{SO}_{4}, 0.1 \mathrm{wt} \% \mathrm{FeSO}_{4}, 20 \mathrm{wt} \% \mathrm{MgSO}_{4}, 6 \mathrm{M} \mathrm{KOH}$, $0.05 \mathrm{wt} \%$ vitamin $\mathrm{B} 1$ and $10 \mathrm{wt} \%$ glucose) adjusted to a $\mathrm{pH}$ of 6.8 was sterilized by autoclaving for $20 \mathrm{~min}$ at $121{ }^{\circ} \mathrm{C}$ and 100 $\mathrm{kPa}$ before being used for the culture of bacterial cells.

2.2.2. Microbial cell culture. Bacteria from frozen stock were inoculated onto a lysogeny broth (LB) agar plate $\left(15 \mathrm{~g} \mathrm{~L}^{-1}\right.$ in water) and incubated overnight at $30^{\circ} \mathrm{C}$. A first pre-culture was prepared from one colony of the cultivated bacteria in $10 \mathrm{~mL}$ of fresh M63G medium and incubated at $30{ }^{\circ} \mathrm{C}$ for $14 \mathrm{~h}$. A second pre-culture was prepared from the first pre-culture (10 vol\% dilution) in $10 \mathrm{~mL}$ of fresh M63G medium and cultivated at $30^{\circ} \mathrm{C}$ for $4 \mathrm{~h}$. The bacterial suspension was centrifuged for $30 \mathrm{~min}$ at $30000 \mathrm{rpm}$, and the pellet was re-suspended in $4 \mathrm{~mL}$ of fresh M63G medium. The absorbance of a bacterial suspension containing about $5 \times 10^{6}$ bacteria per $\mathrm{mL}$ measured at $600 \mathrm{~nm}$ $\left(\mathrm{Abs}_{600 \mathrm{~nm}}\right)$ was adjusted to 0.05 . This final bacterial suspension was used to perform bacterial colonization experiments on the zinc phosphate materials.
2.2.3. Zinc phosphate materials used for microbiological assays. The antibacterial activity of the zinc phosphate materials was investigated after calcination at $750{ }^{\circ} \mathrm{C}(\mathrm{ZnPOs}-750$ and ZnPOs/Ag-750). A polished silicon wafer (SW) disk cut into squares (about $10 \mathrm{~mm} \times 10 \mathrm{~mm}$ ) was used as a control in the bacterial colonization assays. Zinc phosphates in powder form ( $m=80-100 \mathrm{mg}$ ) were introduced into small sterile glass containers (diameter of $10 \mathrm{~mm}$ and height of $3 \mathrm{~mm}$ ) until they were almost completely filled. The glass containers with zinc phosphates were then placed in Petri dishes (diameter of $35 \mathrm{~mm}$ and height of $10 \mathrm{~mm}$ ). The calcined material samples were sterilized by the thermal treatment at $750{ }^{\circ} \mathrm{C}$ for $4 \mathrm{~h}$. Silicon wafer samples were sterilized by dry heating at $180^{\circ} \mathrm{C}$ for $1 \mathrm{~h}$. All further manipulations of material samples in the microbiological assays were performed under sterile conditions.

2.2.4. Bacterial colonization of zinc phosphates. Material samples were inoculated with $4 \mathrm{~mL}$ of a bacterial suspension with an $\mathrm{Abs}_{600} \mathrm{~nm}$ value of 0.05 . They were incubated for periods of $2 \mathrm{~h}$ and $3 \mathrm{~h}$ at $30^{\circ} \mathrm{C}$. The samples were then carefully rinsed with a fresh solution of $\mathrm{NaCl}\left(9 \mathrm{~g} \mathrm{~L}^{-1}\right.$ in water) to eliminate non-adherent bacteria from the material surface. For this purpose, $1 \mathrm{~mL}$ of liquid was removed by putting a pipette tip onto the wall of the Petri dish without touching the material surface and was replaced by $1 \mathrm{~mL}$ of a fresh solution of $\mathrm{NaCl}$. This rinsing process was repeated 8 times. The material samples were kept immersed in the liquid during rinsing to avoid any detachment of adherent bacteria by the creation of a material-air interface.

Colonization by bacteria of the material samples was analyzed in situ in the last rinsing medium under a confocal laser scanning microscope (Carl Zeiss LSM700) equipped with a $63 \times$ water immersion objective (working distance of 2.4 $\mathrm{mm}) .{ }^{48}$ Fluorescence and reflection images were taken at the same time at 6 different locations on each material sample. Excitation sources at $488 \mathrm{~nm}$ and $405 \mathrm{~nm}$, respectively, and a 490-555 $\mathrm{nm}$ bandpass emission filter were used for fluorescence data capture. At each location, stacks of $2 \mathrm{D} x, y$ images (at intervals of $1 \mu \mathrm{m}$ in the $z$-direction) were acquired. In each experiment, one sample of each type of material was used. The experiment was repeated 6 times.

2.2.5. Effect of release of $\mathbf{A g}^{+}$ions on bacterial viability. The effect of the release of silver ions from Ag nanoparticles on the viability of adherent bacteria was investigated by staining with red-fluorescent propidium iodide (PI) $\left(1 \mathrm{~g} \mathrm{~L}^{-1}, \geq 94 \%\right.$, Sigma-Aldrich), which penetrates bacteria with a damaged membrane. ${ }^{\mathbf{4 9 , 5 0}}$ As the last rinsing step, the material samples were rinsed with a solution of $\mathrm{PI}$ in $\mathrm{NaCl}$ with a concentration of $4 \mathrm{mg} \mathrm{L}{ }^{-1}$. They were then incubated for $15 \mathrm{~min}$ at $30^{\circ} \mathrm{C}$. The material samples were analyzed by confocal laser scanning microscopy according to the procedure described above, with emission fluorescence recorded in the range of 600-700 nm and excitation at $555 \mathrm{~nm}$. Quantification of $\mathrm{Ag}^{+}$ions released into the liquid was performed by ICP-AES in specific experiments. Samples were exposed to $4 \mathrm{~mL}$ of M63G medium free from bacteria for $3 \mathrm{~h}$ at $30{ }^{\circ} \mathrm{C}$. 
2.2.6. Image processing and statistical treatment. Adherent bacteria on material surfaces were quantified from fluorescence micrographs using ImageJ ${ }^{\circledR} 1.50 \mathrm{~b}$ software and plugins..$^{51}$ A total of 36 images were analyzed for each sample, which enabled the calculation of the mean value and standard deviation associated with each type of material. The significance of the results was determined using the statistical Student's $t$-test with a 95\% confidence interval.

2.2.7. Bacterial growth in zinc phosphate environment. The antibacterial effect of the zinc phosphate materials and casein powder on bacteria growing without direct contact with the materials was investigated by a plate diffusion assay in their as-synthesized forms ( $\mathrm{ZnPO} / \mathrm{CN}$ and $\mathrm{ZnPO} / \mathrm{CN} / \mathrm{Ag}$ ) and after calcination at $750{ }^{\circ} \mathrm{C}$ (ZnPOs-750 and ZnPOs/Ag-750). Because the as-synthesized material samples were prepared at high temperatures for a sufficiently long period of synthesis $\left(100{ }^{\circ} \mathrm{C}\right.$ and 6 days), the material samples were used without any additional sterilization treatments to prevent degradation of casein. The calcined material samples were sterilized by the thermal treatment at $750{ }^{\circ} \mathrm{C}$ for $4 \mathrm{~h}$. Agar plates of LB medium containing 5 spaced wells (diameter of $5 \mathrm{~mm}$ and height of $4 \mathrm{~mm}$ ) were fabricated using previously sterilized cylindrical templates of Teflon®. A $100 \mu \mathrm{L}$ sample of a fresh bacterial suspension $\mathrm{Abs}_{600 \mathrm{~nm}}$ of 0.50 , prepared from one colony of bacteria in $10 \mathrm{~mL}$ of $\mathrm{M} 63 \mathrm{G}$ medium and cultivated for $14 \mathrm{~h}$ at $30{ }^{\circ} \mathrm{C}$ ) was carefully spread on an LB agar plate. The wells were filled with samples of the zinc phosphates and casein reagent, as used for the preparation of zinc phosphate, and incubated overnight at $30{ }^{\circ} \mathrm{C}$. Bacterial growth around the samples was examined to identify the potential presence of a growth inhibition zone (expressed in $\mathrm{cm}^{2}$ ). The experiment was conducted in triplicate.

\section{Results and discussion}

\subsection{Preparation and characterization of zinc phosphates loaded with Ag nanoparticles}

As-synthesized zinc phosphates named as ZnPO/CN/Ag (ZnPO $=$ zinc phosphate, $\mathrm{CN}=$ casein, $\mathrm{Ag}=$ silver) and $\mathrm{ZnPO} / \mathrm{CN}$ (reference) were prepared via the same procedure, and the molar compositions of the starting mixtures are reported in Table 1.

Fig. 1 shows the XRD patterns of as-synthesized $\mathrm{ZnPO} / \mathrm{CN} / \mathrm{Ag}$ and $\mathrm{ZnPO} / \mathrm{CN}$. Two compounds were identified in each sample: (i) a major amorphous phase characterized by two broad peaks centered at $9^{\circ}$ and $19^{\circ}(2 \theta)$, which are ascribed to amorphous casein (Fig. 1c), and (ii) a crystalline zinc phosphate phase identified as hopeite $\left(\mathrm{Zn}_{3}\left(\mathrm{PO}_{4}\right)_{2} \cdot 4 \mathrm{H}_{2} \mathrm{O}\right.$, PDF 00-037-0465). The

Table 1 Molar compositions of the starting mixtures heated at $100^{\circ} \mathrm{C}$ for 6 days

\begin{tabular}{|c|c|c|c|c|c|c|}
\hline Sample & $\mathrm{ZnO}$ & $\mathrm{P}_{2} \mathrm{O}_{5}{ }^{a}$ & $\mathrm{Na}_{2} \mathrm{O}$ & $\mathrm{H}_{2} \mathrm{O}$ & $\mathrm{Ag}^{+}$ & $\mathrm{pH}$ \\
\hline $\mathrm{ZnPO} / \mathrm{CN} / \mathrm{Ag}$ & 1 & 0.093 & 0.027 & 1085 & 0.021 & \\
\hline $\mathrm{ZnPO} / \mathrm{CN}$ & & & & & 0 & 4.5 \\
\hline
\end{tabular}

${ }^{a} \mathrm{P}$ from casein protein $(0.71 \mathrm{wt} \%$ of $\mathrm{P})$.

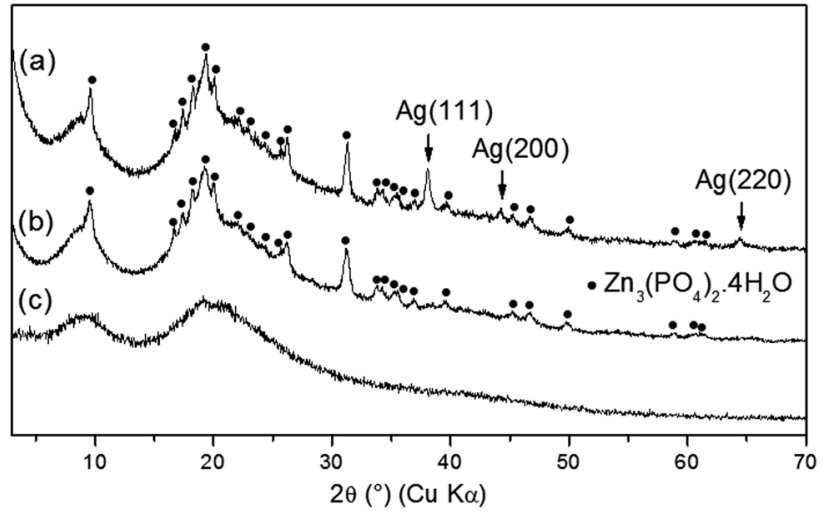

Fig. 1 XRD patterns of as-synthesized products obtained by a hydrothermal procedure at $100{ }^{\circ} \mathrm{C}$ for 6 days: (a) $\mathrm{ZnPO} / \mathrm{CN} / \mathrm{Ag}$, (b) ZnPO/CN and (c) casein powder.

$\mathrm{ZnPO} / \mathrm{CN} / \mathrm{Ag}$ sample contained an additional Ag phase characterized by three peaks observed at $38.1^{\circ}, 44.2^{\circ}$ and $64.4^{\circ}(2 \theta)$ (Fig. 1a), which correspond to the (111), (200) and (220) diffraction planes of face-centered cubic $(f c c)$ silver, respectively (PDF 00-004-0783). No diffraction peaks of silver oxide or other impurities were detected. The XRD results reveal that the crystallization of $\mathrm{Ag}$ was not hampered by the co-crystallization of hopeite. Using the XRD Scherrer method, an average Ag crystal size of $27 \mathrm{~nm}$ was determined.

TEM images and the particle size distribution of the $\mathrm{ZnPO} /$ $\mathrm{CN} / \mathrm{Ag}$ sample are shown in Fig. 2. The TEM observations reveal the presence of spherical $\mathrm{Ag}$ nanoparticles that are fairly well distributed in the solid. Their size distribution has an average value of $26.6 \pm 10.4 \mathrm{~nm}$, with some aggregates with sizes ranging from $40 \mathrm{~nm}$ to $60 \mathrm{~nm}$. These results are in agreement with the value obtained by the Scherrer method.

The formation of Ag nanoparticles was initially a result of the incorporation of the silver nitrate solution to disperse casein micelles in the acidic medium $(\mathrm{pH} \sim 5)$. This involved the formation of casein- $\mathrm{Ag}^{+}$ion complexes thanks to electrostatic interactions between $\mathrm{Ag}^{+}$ions and functional groups of amino acids present in casein molecules such as amine $\left(-\mathrm{NH}_{2}\right)$, thiol $(-\mathrm{SH})$ and carboxyl $(-\mathrm{COOH})$ groups. ${ }^{39,40}$ At this stage, no evident difference in color was observed between the casein $/ \mathrm{Ag}^{+}$ions dispersion and the casein dispersion (reference), which suggested that Ag particles were not immediately formed, at least at room temperature. The concentration of $\mathrm{NaOH}$ (i.e., $3.0 \mathrm{mmol}$ $\mathrm{L}^{-1}$ ) may have been too low to promote the reducing capacity of casein protein, which led to incomplete reduction of $\mathrm{Ag}$ ions. ${ }^{\mathbf{4 0}}$ The final incorporation of the zinc nitrate solution in the casein $/ \mathrm{Ag}^{+}$ions dispersion, which led to a $\mathrm{pH}$ of 4.2 , caused the solubilization of colloidal calcium phosphate (CCP) (inorganic phosphorus) present in casein molecules. ${ }^{52}$ Released phosphate ions reacted with $\mathrm{Zn}^{2+}$ ions, which resulted in the formation of hopeite. Moreover, the dark brown color of the product obtained via synthesis at $100{ }^{\circ} \mathrm{C}$ suggests the formation of $\mathrm{Ag}$ particles in the solid in contrast to the brown product obtained without silver (reference sample). This suggests that previously formed casein $-\mathrm{Ag}^{+}$ion complexes reacted in situ to provide $\mathrm{Ag}$ 

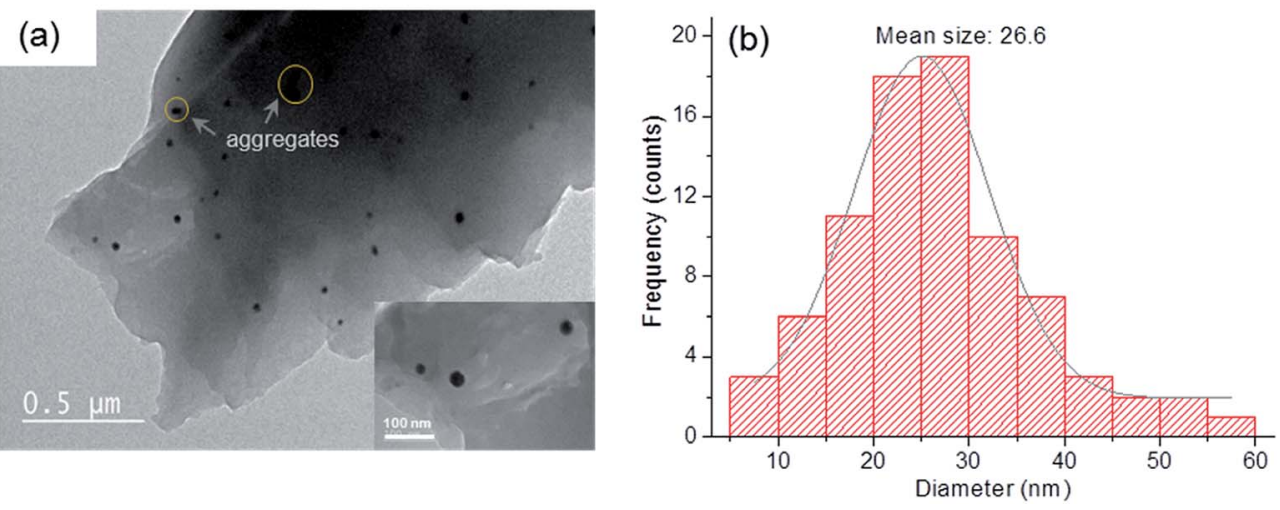

Fig. 2 (a) TEM image of as-synthesized ZnPO/CN/Ag (inset: magnified image of Ag nanoparticles) and (b) particle size distribution of Ag in the sample.

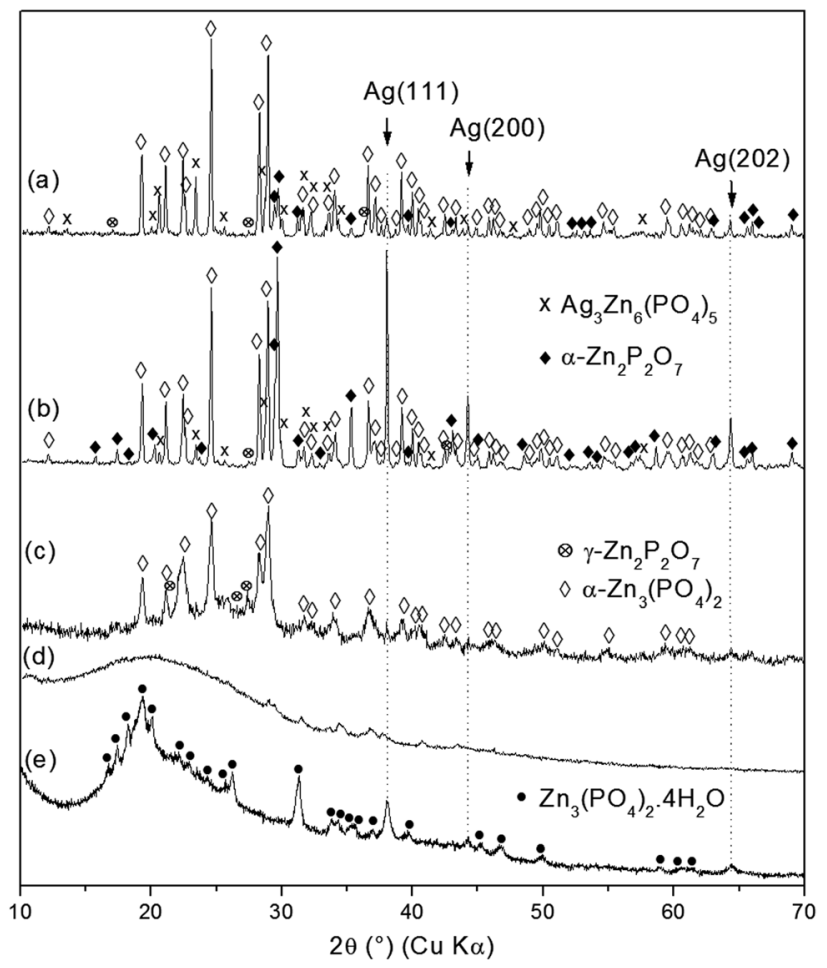

Fig. $3 \mathrm{XRD}$ patterns of as-synthesized $\mathrm{ZnPO} / \mathrm{CN} / \mathrm{Ag}$ calcined at temperatures of between $250^{\circ} \mathrm{C}$ and $750^{\circ} \mathrm{C}$ for $4 \mathrm{~h}$ with a heating rate of $5^{\circ} \mathrm{C} \mathrm{min}^{-1}$ : (a) $\mathrm{ZnPO} / \mathrm{Ag}-750$; (b) $\mathrm{ZnPO} / \mathrm{Ag}-600$; (c) $\mathrm{ZnPO} / \mathrm{Ag}-500$; (d) $\mathrm{ZnPO} / \mathrm{Ag}-250$; (e) $\mathrm{ZnPO} / \mathrm{CN} / \mathrm{Ag}$. particles, which were probably stabilized by casein as previously observed by Ashraf et al. ${ }^{39}$

\subsection{Calcination conditions}

As-synthesized $\mathrm{ZnPO} / \mathrm{CN} / \mathrm{Ag}$ samples were calcined at different temperatures ranging from $250{ }^{\circ} \mathrm{C}$ to $750{ }^{\circ} \mathrm{C}$ to investigate thermal influences on the crystallization process (Fig. 3, Table 2). The XRD results for the sample heated at $250{ }^{\circ} \mathrm{C}$ show a broad band centered at about $20^{\circ}(2 \theta)$ (casein) and a few small unidentified peaks (Fig. 3d). This indicates the transformation of hopeite via thermal treatment. The absence of a signal for crystalline silver suggests possible thermal instability of the Ag nanoparticles in the presence of casein associated with the low sensitivity of the diffractometer used for the calcined samples. The amorphous solid recrystallized at $500{ }^{\circ} \mathrm{C}$ (Fig. 3c), mainly into zinc orthophosphate $\left(\alpha-\mathrm{Zn}_{3}\left(\mathrm{PO}_{4}\right)_{2}\right)$ (PDF 00-029-1390). At higher calcination temperatures ranging from $600{ }^{\circ} \mathrm{C}$ to $750{ }^{\circ} \mathrm{C}$ (Fig. 3a and b), crystallization of $\alpha-\mathrm{Zn}_{2} \mathrm{P}_{2} \mathrm{O}_{7}$ (PDF 00-008-038) occurred, which was probably induced by phosphate groups of phosphoserine residues released during the combustion of casein. In addition, better crystallization of $\mathrm{Ag}^{0}$ was observed at $600{ }^{\circ} \mathrm{C}$, as indicated by the sharpening and higher intensity of the $\mathrm{Ag}$ peaks at $38.1^{\circ}, 44.2^{\circ}$ and $64.4^{\circ}(2 \theta)$. Another compound, which was probably silver zinc orthophosphate of the $\mathrm{Ag}_{3} \mathrm{Zn}_{6}(-$ $\left.\mathrm{PO}_{4}\right)_{5}$ type (PDF 00-038-0302), crystallized at and above $600{ }^{\circ} \mathrm{C}$. This may result from either $\mathrm{Ag}$ nanoparticles that were oxidized by $\mathrm{PO}_{4}{ }^{3-}$ species present in the sample,$^{53,54}$ as indicated by the decrease in the intensity of $\mathrm{Ag}$ peaks at $750{ }^{\circ} \mathrm{C}$, or silver atoms

Table 2 Results of XRD analyses of samples of ZnPO/CN/Ag calcined at different temperatures

\begin{tabular}{|c|c|c|}
\hline Sample & Temperature $\left({ }^{\circ} \mathrm{C}\right)$ & Result (XRD) \\
\hline $\mathrm{ZnPO} / \mathrm{CN} / \mathrm{Ag}$ & RT & Casein $^{a}+$ hopeite $^{b}+\mathrm{Ag}$ \\
\hline ZnPOs/Ag-250 & 250 & a.p. ${ }^{c}+$ nid (traces) \\
\hline $\mathrm{ZnPOs} / \mathrm{Ag}-500$ & 500 & $\alpha-\mathrm{Zn}_{3}\left(\mathrm{PO}_{4}\right)_{2}{ }^{a}+\gamma-\mathrm{Zn}_{2} \mathrm{P}_{2} \mathrm{O}_{7}$ (traces) + a.p. ${ }^{c}, \mathrm{Ag}($ traces $)$ \\
\hline ZnPOs/Ag-600 & 600 & $\mathrm{Ag}+\alpha-\mathrm{Zn}_{3}\left(\mathrm{PO}_{4}\right)_{2}+\alpha-\mathrm{Zn}_{2} \mathrm{P}_{2} \mathrm{O}_{7}+\gamma-\mathrm{Zn}_{2} \mathrm{P}_{2} \mathrm{O}_{7}$ (traces) $+\mathrm{Ag}_{3} \mathrm{Zn}_{6}\left(\mathrm{PO}_{4}\right)_{5}$ (traces) \\
\hline ZnPOs/Ag-750 & 750 & $\alpha-\mathrm{Zn}_{3}\left(\mathrm{PO}_{4}\right)_{2}{ }^{a}+\alpha-\mathrm{Zn}_{2} \mathrm{P}_{2} \mathrm{O}_{7}+\mathrm{Ag}+\gamma-\mathrm{Zn}_{2} \mathrm{P}_{2} \mathrm{O}_{7}$ (traces) $+\mathrm{Ag}_{3} \mathrm{Zn}_{6}\left(\mathrm{PO}_{4}\right)_{5}$ \\
\hline
\end{tabular}

${ }^{a}$ Major phase. ${ }^{b} \mathrm{Zn}_{3}\left(\mathrm{PO}_{4}\right)_{2} \cdot 4 \mathrm{H}_{2} \mathrm{O} .{ }^{c}$ a.p.: amorphous phase. RT: room temperature (sample before calcination). nid: not identified. 
Table 3 Results of chemical analyses (weight \%) of casein and as-synthesized and calcined (at $750{ }^{\circ} \mathrm{C}$ ) samples

\begin{tabular}{lllll}
\hline Sample & $\mathrm{Ag}(\%)$ & $\mathrm{Ca}(\%)$ & $\mathrm{P}(\%)$ & $\mathrm{Zn}(\%)$ \\
\hline ZnPO/CN & - & $<0.003$ & $0.84( \pm 0.03)$ & $1.04( \pm 0.41)$ \\
ZnPO/CN/Ag & $0.57 \pm 0.01$ & $<0.003$ & $15.60( \pm 0.54)$ & $2.41( \pm 0.06)$ \\
ZnPOs-750 & - & $0.063( \pm 0.002)$ & $14.07( \pm 0.48)$ & $4.09( \pm 0.06)$ \\
ZnPOs/Ag-750 & $6.39 \pm 0.26$ & $0.105( \pm 0.003)$ & $0.77( \pm 0.03)$ & $46.75( \pm 1.40)$ \\
Casein & - & $0.145( \pm 0.004)$ &
\end{tabular}

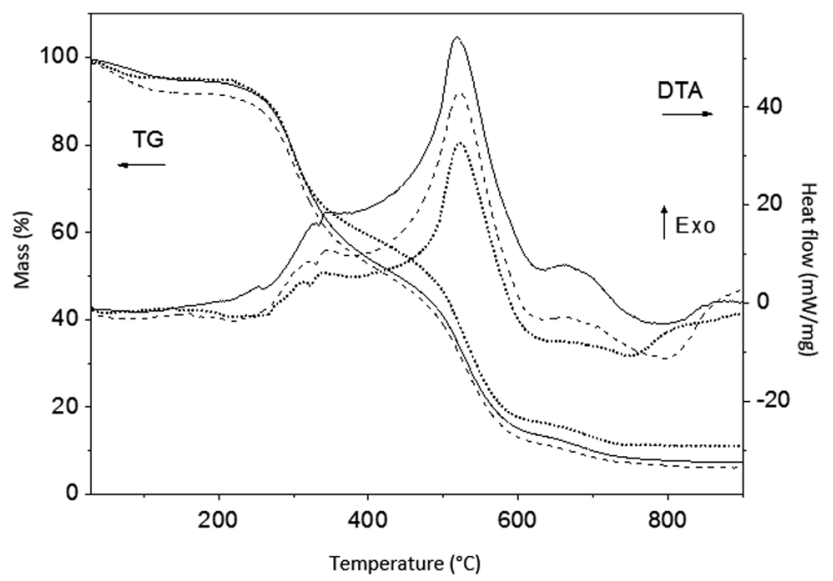

Fig. 4 TGA and DTA results obtained under air for $\mathrm{ZnPO} / \mathrm{CN} / \mathrm{Ag}$ (black curves), ZnPO/CN (dashed black curves) and casein powder (dotted black curves).

Table 4 Weight loss percentages for as-synthesized ZnPO/CN/Ag and $\mathrm{ZnPO} / \mathrm{CN}$ determined from the TGA curves

\begin{tabular}{lll}
\hline Sample & $\begin{array}{l}\text { Up to } 200{ }^{\circ} \mathrm{C} \\
(\text { wt\%) }\end{array}$ & $\begin{array}{l}\text { From } 200{ }^{\circ} \mathrm{C} \\
\text { to } 780{ }^{\circ} \mathrm{C}(\mathrm{wt} \%)\end{array}$ \\
\hline $\mathrm{ZnPO} / \mathrm{CN} / \mathrm{Ag}$ & 5.7 & 86.4 \\
$\mathrm{ZnPO} / \mathrm{CN}$ & 8.5 & 84.6
\end{tabular}

not involved in the crystallization of $\mathrm{Ag}^{0}$ at temperatures of less than $600{ }^{\circ} \mathrm{C}$ that participated in the crystallization of this new compound. Furthermore, in the absence of $\mathrm{Ag}$ in the starting mixture, the same zinc phosphate phases crystallized (i.e., $\alpha-$ $\mathrm{Zn}_{3}\left(\mathrm{PO}_{4}\right)_{2}$ and $\gamma$ - and $\alpha-\mathrm{Zn}_{2} \mathrm{P}_{2} \mathrm{O}_{7}$, hopeite) ${ }^{37}$

According to chemical analyses (Table 3), the weight percentages of $\mathrm{Ag}, \mathrm{Zn}$ and $\mathrm{P}$ in $\mathrm{ZnPO} / \mathrm{CN} / \mathrm{Ag}$ were lower than those in ZnPOs/Ag-750, as was expected owing to the predominance of casein in the sample before calcination. Because calcium cations were undetectable in the as-synthesized samples but measurable in casein (i.e., $0.15 \mathrm{wt} \%$ ), colloidal calcium may have been almost completely solubilized and $\mathrm{Ca}^{2+}$ ions eliminated in the filtrate of the as-synthesized sample, while phosphate ions may have been used for the synthesis of hopeite. The presence of calcium in the calcined samples suggests that (i) $\mathrm{Ca}^{2+}$ ions present in the as-synthesized samples were involved in electrostatic interactions with phosphate groups of phosphoserine and (ii) $\mathrm{Ca}^{2+}$ ions compensated for some negative charges that formed in the sample calcined at $750{ }^{\circ} \mathrm{C}$.

Simultaneous TG and DT analyses were performed on the assynthesized $\mathrm{ZnPO} / \mathrm{CN} / \mathrm{Ag}$ and $\mathrm{ZnPO} / \mathrm{CN}$ samples. As was expected because of the large amount of casein in the samples, the TGA and DTA curves shown in Fig. 4 have similar profiles to those of casein. The first loss of weight in the TGA curves between room temperature and $200{ }^{\circ} \mathrm{C}$ is related to physisorbed water. It is associated with the small endothermic peak centered at about $100{ }^{\circ} \mathrm{C}$ in the DTA curves. Three main weight losses that are ascribed to the decomposition of casein are observed between $200^{\circ} \mathrm{C}$ and $780^{\circ} \mathrm{C}$, which are associated with the broad exothermic band with a maximum at about $520{ }^{\circ} \mathrm{C}$. The higher values of exothermic enthalpy observed for $\mathrm{ZnPO} / \mathrm{CN} / \mathrm{Ag}$ in comparison with the $\mathrm{ZnPO} / \mathrm{CN}$ sample suggest that the presence of Ag nanoparticles protected by casein led to an increase in the energy required for the decomposition of casein. The weight losses determined from the TGA curves of the assynthesized $\mathrm{ZnPO} / \mathrm{CN} / \mathrm{Ag}$ and $\mathrm{ZnPO} / \mathrm{CN}$ samples are summarized in Table 4. They indicate that the samples had similar contents of casein.

Furthermore, the influence of the calcination temperature on the particle size of silver nanoparticles was investigated by TEM (Fig. 5). Elemental mapping of $\mathrm{Ag}$ showed highlighted silver nanoparticles and aggregates (larger pink spots). The nanoparticle size was $9.9 \pm 2.7 \mathrm{~nm}, 25.4 \pm 7.5 \mathrm{~nm}$ and $6.4 \pm$ $3.0 \mathrm{~nm}$ for the samples calcined at 500, 600 and $750{ }^{\circ} \mathrm{C}$, respectively. The formation of aggregates of $\mathrm{Ag}$ nanoparticles with sizes of around $80 \mathrm{~nm}$ was most prominent at 600 and $750{ }^{\circ} \mathrm{C}$. Such large aggregates were not observed in the assynthesized sample, in which casein stabilized silver nanoparticles and prevented them from approaching each other. In contrast, they may have formed after the combustion of casein, which led to the decomposition of casein and, therefore, possible close contact between nanoparticles.

SEM analyses of the as-synthesized $\mathrm{ZnPO} / \mathrm{CN} / \mathrm{Ag}$ and ZnPOs/ Ag-500, -600 and -750 samples, as shown in Fig. 6, show that the surfaces of the as-synthesized samples were composed of large irregular particles with undefined shapes and rough surfaces. At $500{ }^{\circ} \mathrm{C}$, pores were formed (diameter: $0.05-0.2 \mu \mathrm{m}$ ). Macroporosity increased at $600{ }^{\circ} \mathrm{C}$ with a heterogeneous pore size distribution (i.e., a range of $0.10-1.70 \mu \mathrm{m}$ ) and an ill-defined pore shape. This macroporosity disappeared at $750{ }^{\circ} \mathrm{C}$ while larger quasi-spherical pores with a heterogeneous pore diameter $(17 \mu \mathrm{m}$ to $100 \mu \mathrm{m})$ were formed (Fig. $6 \mathrm{~d})$. In the case of the sample calcined at $600{ }^{\circ} \mathrm{C}$, silver nanoparticles and aggregates are seen in the SEM images as white particles (Fig. $6 \mathrm{c} 1$ and c2). 

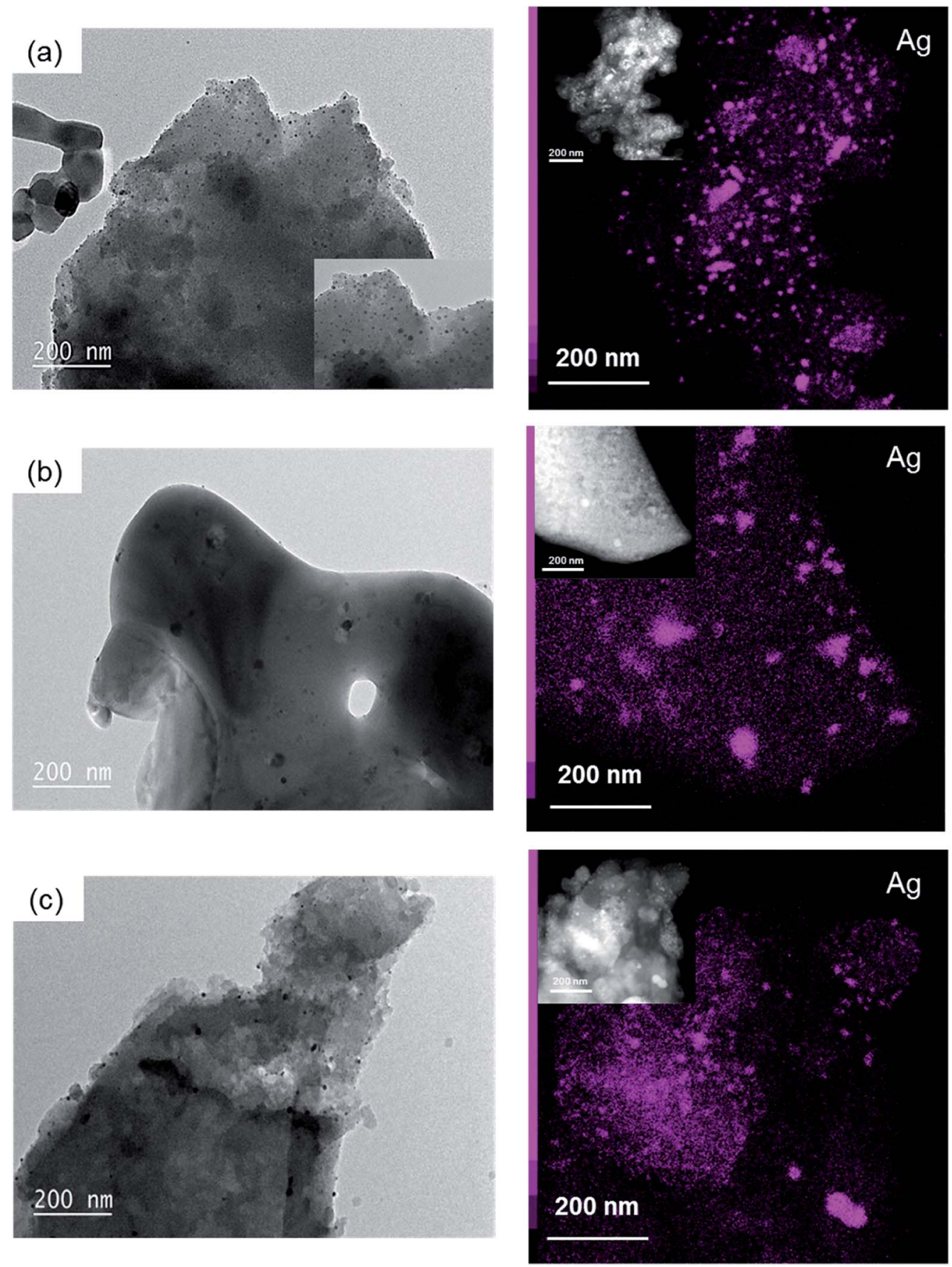

Fig. 5 TEM images and corresponding elemental mapping images of Ag (right) of: (a) ZnPOs/Ag-750, (b) ZnPOs/Ag-600 and (c) ZnPOs/Ag-500.

In addition, nitrogen adsorption measurements revealed that the calcined samples had very small specific surface areas $\left(S_{\mathrm{BET}}<3 \mathrm{~m}^{2} \mathrm{~g}^{-1}\right)$ and did not contain any micro- or mesopores. Complementary analyses performed by $\mathrm{Hg}$ porosimetry on the ZnPOs/Ag-750 sample revealed a broad pore size distribution (10 to $200 \mu \mathrm{m}$ ) with an average diameter of $70 \mu \mathrm{m}$ (Fig. 7). This is mainly attributed to the intra-particle porosity visible in SEM images. The foamy aspect of the material observed after calcination was preserved during the porosity experiments; this proves that the porosity was stable up to a pressure of $200 \mathrm{MPa}$. The $\mathrm{Hg}$ cumulative pore volume was $1.28 \mathrm{~cm}^{3} \mathrm{~g}^{-1}$.

\subsection{Antibacterial activity of zinc phosphates}

Bacterial growth in close proximity to the zinc phosphate materials was investigated by depositing samples onto agar nutrient plates inoculated with a bacterial suspension, which allowed diffusion of compounds from the material. Zones of bacterial growth inhibition were more clearly defined around the ZnPOs/Ag-750 sample $\left(0.79 \pm 0.23 \mathrm{~cm}^{2}\right)$ in comparison with the other samples (Fig. 8). This is ascribed to the antibacterial activity of $\mathrm{Ag}^{+}$ions that were released by the oxidation of $\mathrm{Ag}$ nanoparticles present in the material in contact with the liquid $^{8,9,55}$ and diffused through the agar gel. In contrast, an 

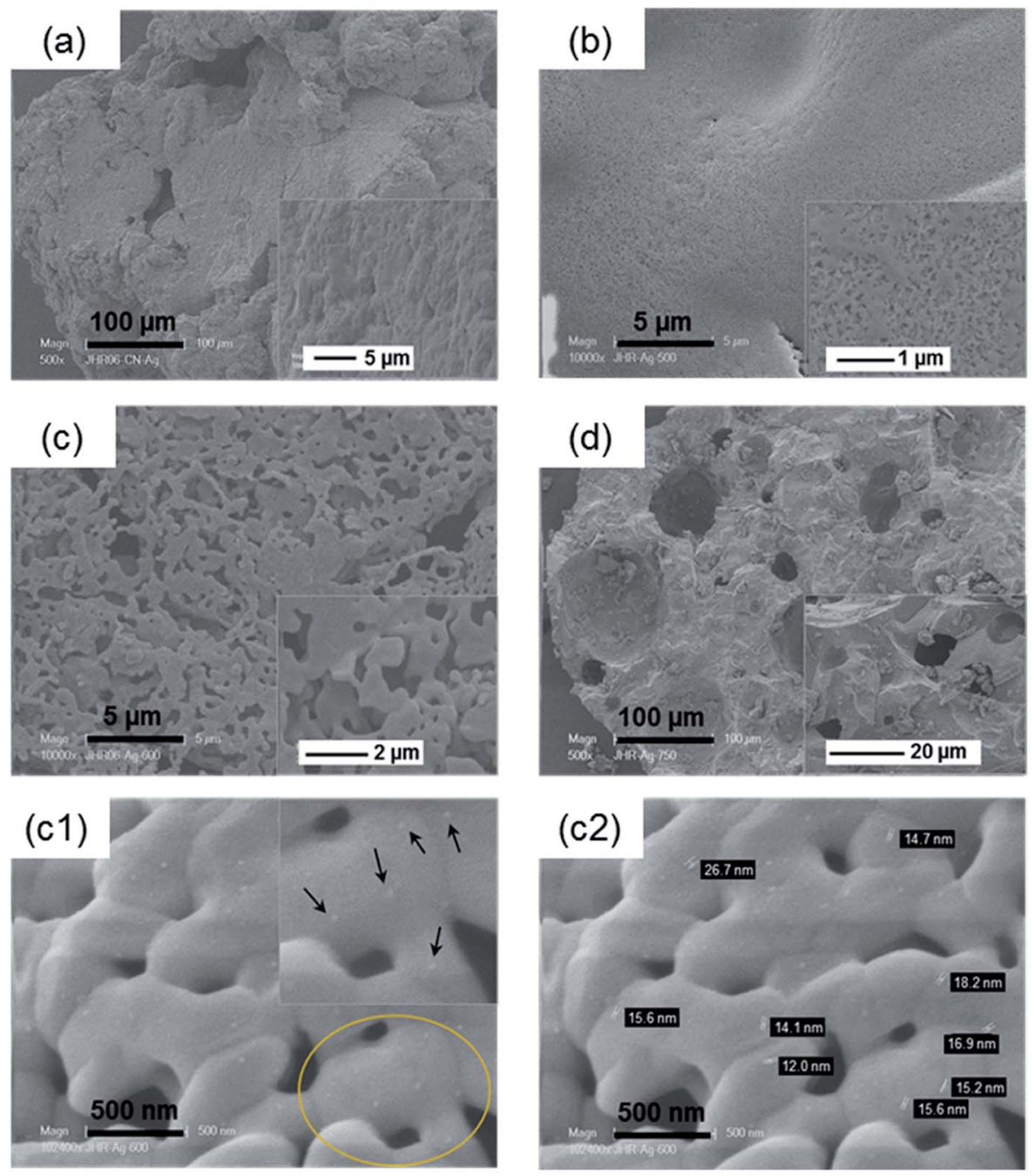

Fig. $6 \mathrm{SEM}$ images of (a) ZnPO/CN/Ag, (b) ZnPOs/Ag-500, (c, c1 and c2) ZnPOs/Ag-600 and (d) ZnPOs/Ag-750. The inset in (c1) displays a magnified image of the enclosed area showing Ag nanoparticles with particle sizes ranging from $14 \mathrm{~nm}$ to $27 \mathrm{~nm}$, which are also observed in (c2).

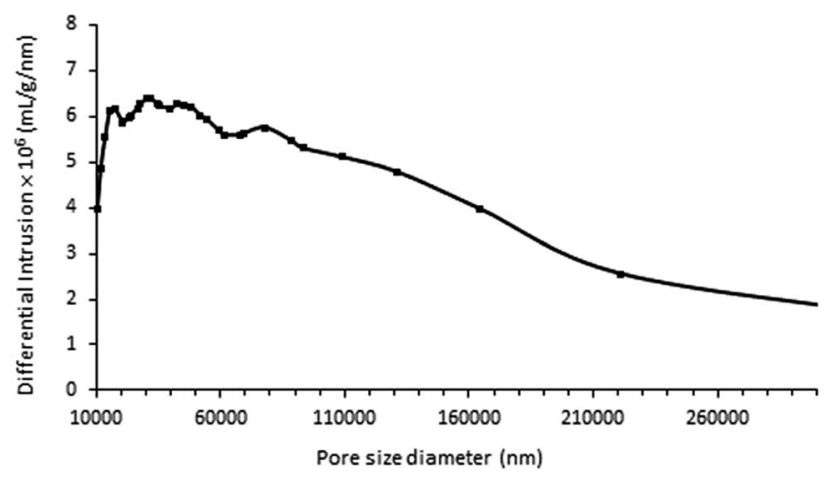

Fig. 7 Pore size distribution of ZnPOs/Ag-750 determined by mercury porosimetry.

inhibition zone was not observed for the $\mathrm{ZnPO} / \mathrm{CN} / \mathrm{Ag}$ samples, which was probably due to the lower silver content (Table 3 and $\mathrm{ESI}, \uparrow$ Table 1). In addition, the results indicate that the Ag-free $\mathrm{ZnPO} / \mathrm{CN}$ and ZnPOs-750 samples did not release a sufficient quantity of any substance able to inhibit the growth of $E$. coli, such as zinc or casein. Pure casein powder, which was used as a positive control, was shown to provide a weak antibacterial effect $\left(0.25 \pm 0.16 \mathrm{~cm}^{2}\right)$ after overnight incubation (Fig. 8), as already reported in the literature. ${ }^{56}$

Bacterial colonization on the ZnPOs-750 and ZnPOs/Ag-750 materials was investigated using the E. coli K12 SCC1 strain (see $\mathrm{ESI} \dagger$ for $\mathrm{ZnPO} / \mathrm{CN}$ and $\mathrm{ZnPO} / \mathrm{CN} / \mathrm{Ag}$ ). Fig. 9a(1-3) shows typical examples of micrographs acquired by confocal fluorescence microscopy after incubation for $3 \mathrm{~h}$. Bacteria were uniformly distributed on all material surfaces and were preferentially located in surface cavities of the ZnPOs-750 and ZnPOs/Ag-750 materials, which were probably formed from macropores (pore diameter between 350 and $1000 \mathrm{~nm}$ ). ${ }^{37} \mathrm{~A}$ quantitative view of colonization after incubation for $2 \mathrm{~h}$ and $3 \mathrm{~h}$ is given in Fig. 9b, which reveals that the number of bacteria was significantly lower on zinc phosphate surfaces in comparison with the SW control and thus shows that the zinc phosphate surfaces were unfavorable for bacterial colonization. 


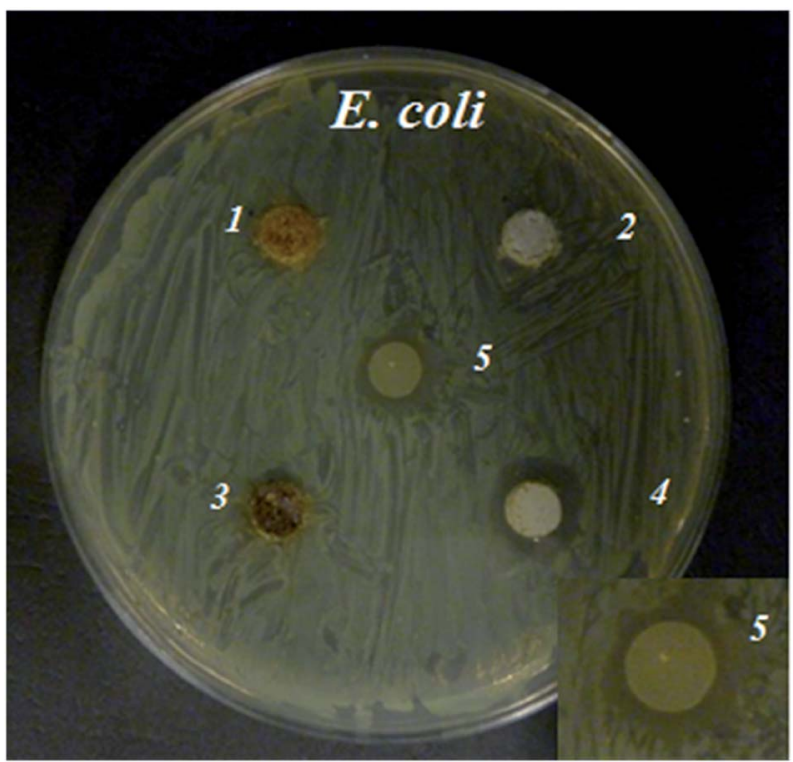

Fig. 8 Antibacterial activity against $E$. coli tested by measuring the zone of growth inhibition after overnight incubation (inset: a magnified image of zone 5): (1) ZnPO/CN, (2) ZnPOs-750, (3) ZnPO/CN/Ag, (4) $\mathrm{ZnPOs} / \mathrm{Ag}-750$ and (5) casein samples on E. coli K12.
The capacity of zinc phosphates to affect bacterial proliferation was also investigated on the basis of a comparison between zinc phosphates in terms of colonization after the materials were exposed to bacteria for $2 \mathrm{~h}$ and $3 \mathrm{~h}$ (see ESI $\dagger$ for $\mathrm{ZnPO} / \mathrm{CN}$ and $\mathrm{ZnPO} / \mathrm{CN} / \mathrm{Ag}$ ). As shown in Fig. 9b, the number of adherent bacteria on the ZnPOs-750 material significantly increased between incubation durations of $2 \mathrm{~h}$ and $3 \mathrm{~h}$ (about $+20 \%$ ) (Table 5), as was expected owing to the normal growth of bacterial populations on surfaces. Nevertheless, it was significantly less than that measured on the SW control (about $+87 \%$ ), which is attributed to the action of ions such as $\mathrm{Zn}^{2+}$ that were released from the zinc phosphate materials (Table 5) and are known to exhibit inhibitory effects on bacteria. ${ }^{57,58}$

Regarding potential antibacterial activity related to the $\mathrm{Ag}$ content of the materials, the results revealed a significant reduction in the bacterial population on an Ag-based (ZnPOs/ $\mathrm{Ag}$-750) in comparison with an Ag-free (ZnPOs-750) material after incubation for $2 \mathrm{~h}$ (Fig. 9b). A significant reduction in the number of adherent bacteria was also observed on ZnPOs/Ag750 between incubation durations of $2 \mathrm{~h}$ and $3 \mathrm{~h}(\sim-19 \%$, Fig. 9b and Table 5). These results are consistent with the antibacterial activity expected for the amount of $\mathrm{Ag}^{+}$measured after release in the $\mathrm{M} 63 \mathrm{G}$ culture medium $\left(10^{-5} \mathrm{M}\right.$, Table 5), i.e.,
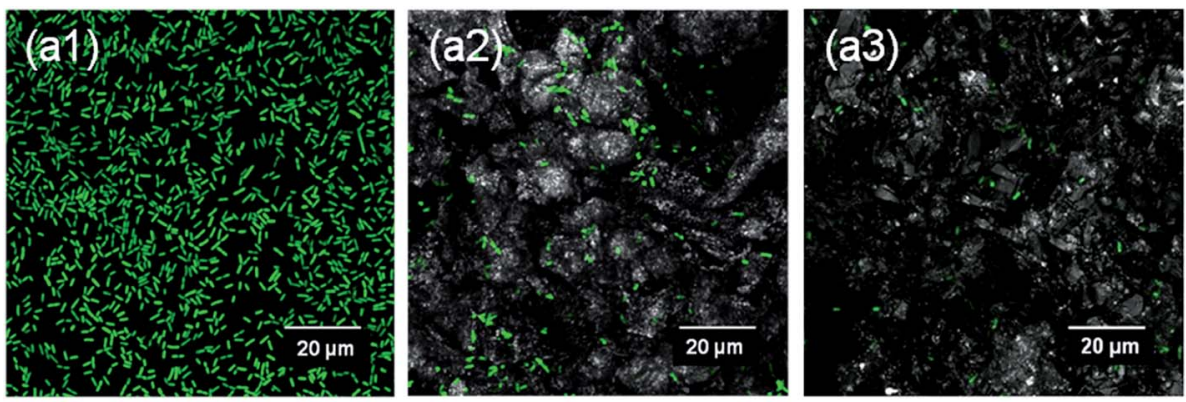

(b)

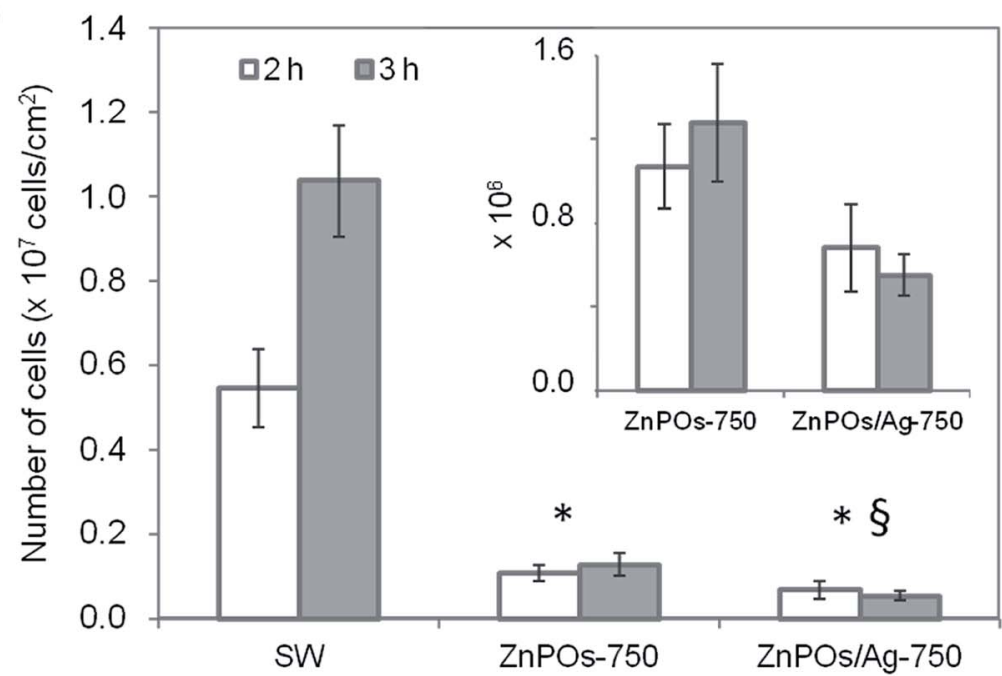

Fig. 9 (a) 2D z-projection of confocal 3D images of E. coli K12 bacteria adherent on (a1) SW, (a2) ZnPOs-750 and (a3) ZnPOs/Ag-750 materials after incubation for $3 \mathrm{~h}$. (b) Number of bacteria on SW control, ZnPOs-750 and ZnPOs/Ag-750 materials after incubation for $2 \mathrm{~h}$ and $3 \mathrm{~h}$ (average of 6 experimental replicates). The * and $\S$ symbols indicate significant differences in comparison with SW and ZnPOs-750, respectively ( $p$-value < 0.05). Inset: a magnified image of the histogram showing the number of bacteria on the ZnPOs-750 and ZnPOs/Ag-750 materials. 
Table 5 Bacterial proliferation calculated from the number of bacteria recorded on porous zinc phosphates after incubation for $2 \mathrm{~h}$ and $3 \mathrm{~h}$ and contents of $\mathrm{Ag}^{+}$and $\mathrm{Zn}^{2+}$ ions in M63G medium after exposure of the porous solids to the medium for $3 \mathrm{~h}$ at $30^{\circ} \mathrm{C}$

\begin{tabular}{llll}
\hline Sample & $\begin{array}{l}\text { \% bacterial } \\
\text { proliferation }(2 \mathrm{~h} \text { to } 3 \mathrm{~h})\end{array}$ & {$\left[\mathrm{Ag}^{+}\right] \mathrm{M}$} & {$\left[\mathrm{Zn}^{2+}\right] \mathrm{M}^{-}$} \\
\hline SW & +87 & - & - \\
ZnPOs-750 & +20 & - & $(6.2 \pm 0.1) \times 10^{-5}$ \\
ZnPOs/Ag-750 & -19 & $(10.0 \pm 0.2) \times 10^{-6}$ & $(7.5 \pm 0.1) \times 10^{-5}$
\end{tabular}

large enough to induce the death of $E$. coli bacteria and a subsequent reduction in the bacterial population (minimum inhibitory concentration of $0.6 \times 10^{-6} \mathrm{M}, 0.4-2.0 \times 10^{-6} \mathrm{M}$ for $\mathrm{Ag}^{+}$, i.e., $\left.\mathrm{AgNO}_{3}\right) .{ }^{9,59-61}$ However, bacterial staining by PI used as a marker of damaged $E$. coli $\mathrm{K} 12$ bacteria showed that bacteria that adhered to the ZnPOs/Ag-750 material displayed an intact membrane after incubation for $3 \mathrm{~h}$, which indicates that the antibacterial activity was lower than that expected for such a released quantity of $\mathrm{Ag}^{+}$ions $\left(10^{-5} \mathrm{M}\right)$. This is ascribed to the specific culture conditions in comparison with studies reported in the literature. In particular, the bacterial strain, culture medium and temperature are parameters known to affect bacterial sensitivity to antibacterial agents. ${ }^{62,63}$ Thus, reported studies $^{\mathbf{6 4 , 6 5}}$ and results obtained by our group using M63G culture medium ${ }^{66}$ have shown that the interactions of $\mathrm{Ag}^{+}$ions with compounds in different media reduce the amount of $\mathrm{Ag}^{+}$ available for antibacterial action. Despite these interactions, however, the results reported here demonstrate that $\mathrm{Ag}^{+}$ions were released from the ZnPOs/Ag-750 material in sufficient amounts to affect both bacterial colonization and proliferation and therefore to endow it with antibacterial properties.

\section{Conclusion}

In this study, bio-sourced macroporous zinc phosphates with Ag nanoparticles (ZnPOs/Ag) were successfully obtained via an original method of synthesis. This new route for the synthesis of silver-based metal phosphates is advantageous because casein (CN) acts as a bio-source of phosphorus, a stabilizer and a reducing agent for the synthesis of $\mathrm{Ag}$ nanoparticles. It also induces intra-particle macroporosity. During calcination of the as-synthesized compounds ( $\mathrm{ZnPO} / \mathrm{CN} / \mathrm{Ag})$, the crystallization of Ag-supported zinc phosphates was improved up to $600{ }^{\circ} \mathrm{C}$. A study of the antibacterial activity of Ag-containing and Ag-free zinc phosphates against E. coli $\mathrm{K} 12$ bacteria demonstrated that porous zinc phosphates inhibited bacterial adhesion over a short incubation period. The antibacterial activity of ZnPOs/ $\mathrm{Ag}-750$, which was related to the release of $\mathrm{Ag}^{+}$ions from the material, indicated significant bactericidal properties and even led to reductions in populations of already adhered E. coli K12. Growth-inhibiting and bactericidal effects were also observed against bacteria present in the environment of the ZnPOs/Ag750 material. To the best of our knowledge, antibacterial activity of zinc phosphates against $E$. coli is reported here for the first time. These materials could be used, for example, in the treatment of cooling water, heating systems and wastewater.
On the other hand, this work confirms the feasibility of the synthesis of (porous) metal phosphates without the use of reactants derived from phosphate rocks. In addition, such a method of synthesis could be extended to the synthesis of other metal-doped phosphates.

\section{Conflicts of interest}

There are no conflicts to declare.

\section{Acknowledgements}

We thank Habiba Nouali for her assistance with mercury intrusion porosimetry.

\section{References}

1 Z. L. Ning, W. J. Li, C. Y. Sun, P. Che and Z. D. Chang, Trans. Nonferrous Met. Soc. China, 2013, 23, 718-724.

2 J. Gu, B. Yang and J. Optoelectron, Adv. Mater., 2008, 2, 405409.

3 M. J. Gimeno, M. Puic, S. Chamorro, J. Molina, R. March, E. Oró, P. Pérez, J. J. Gracenea and J. J. Suay, Prog. Org. Coat., 2016, 95, 46-53.

4 L. Herschke, I. Lieberwith and G. Wegner, J. Mater. Sci.: Mater. Med., 2006, 17, 95-104.

5 L. Herschke, J. Rottstegge, I. Lieberwith and G. Wegner, J. Mater. Sci.: Mater. Med., 2006, 17, 81-94.

6 M. Otsuka, S. Marunaka, Y. Matsuda, A. Ito, P. Layrolle, H. Naito and N. J. Ichinose, J. Biomed. Mater. Res., 2000, 52, 819-824.

7 Y. Sogo, T. Sakurai, K. Onuma and A. Ito, J. Biomed. Mater. Res., 2002, 62, 457-463.

8 G. Franci, A. Falanga, S. Galdiero, L. Palomba, M. Rai, G. Morelli and M. Galdiero, Molecules, 2015, 20, 8856-8874.

9 C. Greulich, D. Braun, A. Peetsch, J. Diendorf, B. Siebers, M. Epple and M. Köller, RSC Adv., 2012, 2, 6981-6987.

10 P. Daugela, R. Oziunas and G. Zekonis, Stomatologija, 2008, 10, 16-21.

11 R. P. Vokus, G. J. Cisneros and M. Levi, Pediatr. Dent. J., 1998, 20, 43-48.

12 E. V. Dastjerdie, M. Oskoui, E. Sayanjali and F. S. Tabatabaei, Iran. J. Pharm. Res., 2012, 11, 77-82.

13 J. Chou, J. Hao, S. Kuroda, D. Bishop, B. Ben-Nissan, B. Milthorpe and M. Otsuka, Foraminifera Carbonate Macrospheres, Mar. Drugs, 2013, 11, 5148-5158. 
14 X. Liu, Y. Shao, M. Liu, S. Chen, F. Wang and L. Wang, RSC Adv., 2016, 6, 46479-46486.

15 Phosphate Rock, U.S. Geological Survey, Mineral Commodity Summaries, January 2016, pp. 124-125.

16 J. D. Edixhoven, J. Gupta and H. H. G. Savenije, Earth Syst. Dynam., 2014, 5, 491-507.

17 S. J. V. Kauwenbergh, World Phosphate Rock Reserves and Resources, International Center for Soil Fertility and Agricultural Development, 2010, vol. 75, p. 58.

18 J. Patarin, J. L. Paillaud and H. Kessler, in Handbook of Porous Solids, ed. F. Schüth, K. S. W. Sing and J. Weitkamp, Wiley-VCH Verlag GmbH, Germany, 2002, vol. 2, pp. 815-876.

19 S. Y. Liau, S. D. C. Read, W. J. Pugh, J. R. Furr and A. D. Russell, Lett. Appl. Microbiol., 1997, 25, 279-283.

20 J. R. Morones, J. L. Elechiguerra, A. Camacho, K. Holt, J. B. Kouri, J. T. Ramirez and M. J. Jacaman, Nanotechnology, 2005, 16, 2346-2353.

21 N. Durán, M. Durán, M. B. de Jesus, A. B. Seabra, W. J. Fávaro and G. Nakazato, Nanomedicine, 2016, 12, 789-799.

22 D. Jiraroj and S. Tungasmita, Powder Technol., 2014, 264, 418-422.

23 Y. Lv, H. Liu, Z. Wang, S. Liu, L. Hao, Y. Sang, D. Liu, J. Wang and R. I. Boughton, J. Membr. Sci., 2009, 331, 50-56.

24 S. Saengmee-Anupharb, T. Srikhirin, B. Thaweboon, S. Thaweboon, T. Amornsakchai, S. Dechkunakorn and T. Suddhasthira, Asian Pac. J. Trop. Biomed., 2013, 3, 47-52.

25 Q. Wang, H. Yu, L. Zhong, J. Liu, J. Sun and J. Shen, Chem. Mater., 2006, 18, 1988-1994.

26 M. Diaz, F. Barba, M. Miranda, F. Guitian, R. Torrecillas and J. S. Moya, J. Nanomater., 2009, 498-505.

27 J. K. Liu, X. H. Yang and X. G. Tian, Powder Technol., 2008, 184, 21-24.

28 B. Tian, W. Chen, Y. Dong, J. V. Marymont, Y. Lei, Q. Ke, Y. Guo and Z. Zhu, RSC Adv., 2016, 6, 8549-8562.

29 L. Yang, X. Ning, Q. Xiao, K. Chen and H. Zhou, J. Biomed. Mater. Res., Part B, 2007, 81, 50-56.

30 G. Nangmenyi, Z. Yue, S. Mehrabi, E. Mintz and J. Economy, Nanotechnology, 2009, 20, 495705.

31 H. Van der Laan, D. Van Halem, P. W. M. H. Smeets, A. I. A. Soppe, J. Kroesbergen, G. Wubbels, J. Nederstigt, I. Gensburger and S. G. J. Heijman, Water Res., 2014, 51, 47-54.

32 I. De la Rosa-Goméz, M. T. Olguín and D. Alcántara, J. Environ. Manage., 2008, 88, 853-863.

33 L. Akhigbe, S. Ouki and D. Saroj, Chem. Eng. J., 2016, 295, 9298.

34 C. Qi, Y. J. Zhu, X. Y. Zhao, B. Q. Lu, Q. L. Tang, J. Zhao and F. Chen, Eur. J. Chem., 2013, 19, 981-987.

35 C. Qi, Y. J. Zhu, B. Q. Lu, X. Y. Zhao, J. Zhao, F. Chen and J. Wu, Eur. J. Chem., 2013, 19, 5332-5341.

36 G.-J. Ding, Y.-J. Zhu, C. Qi, T.-W. Sun, J. Wu and F. Chen, RSC Adv., 2015, 5, 40154-40162.

37 J. Hinostroza-Ramos, L. Ploux, K. Anselme, L. Balan and A. Simon-Masseron, Cryst. Growth Des., 2016, 16, 4897-4904.

38 Y. D. Livney, Curr. Opin. Colloid Interface Sci., 2010, 15, 7383.
39 S. Ashraf, A. Z. Abbasi, C. Pfeiffer, S. Z. Hussain, Z. M. Khalid, P. R. Gil and W. J. Parak, Colloids Surf., B, 2013, 102, 511-518. 40 G. Ghodake, S. R. Lim and D. S. Lee, Colloids Surf., B, 2013, 108, 147-151.

41 World Health Organization, Guidelines for Drinking-Water Quality, 4th edn, WHO Library, Geneva, 2011.

42 J. Tobias, E. Kassem, U. Rubinstein, A. Bialik, S. R. Vutukuru, A. Navaro, A. Rokney, L. Valinsky, M. Ephros, D. Cohen and K. Muhsen, BMC Infect. Dis., 2015, 15, 79.

43 The International Center for Diffraction Data (ICCD), http:// www.icdd.com (accessed November 2016).

44 E. W. Washburn, Phys. Rev., 1921, 17, 273-283.

45 H. Miao, S. Ratnasingam, C. S. Pu, M. M. Desai and C. C. Sze, J. Microbiol. Methods, 2009, 76, 109-119.

46 R. Heim, D. C. Prasher and R. Y. Tsien, Proc. Natl. Acad. Sci. U. S. A., 1994, 9, 12501-12504.

47 O. Vidal, R. Longin, C. Prigent-Combaret, C. Dorel, M. Hooreman and P. Lejeune, J. Bacteriol., 1998, 180, 2442-2449.

48 M. Veuillet, Doctoral dissertation, Haute-Alsace University, Mulhouse, France, 2017.

49 J. Lehtinen, J. Nuutila and E. M. Lilius, Cytometry, Part A, 2004, 60, 165-172.

50 M. D. Adhikari, B. R. Panda, U. A. Chattopadhyay and A. Ramesh, RSC Adv., 2012, 2, 1782-1793.

51 W. Rasband, ImageJ, U.S. National Institutes of Health, Bethesda, Maryland, USA, 1997.

52 A. Gonzales, P. Thomar, T. Nicolai and J. Dittmer, Food Hydrocolloids, 2015, 51, 88-94.

53 M. Quarton, M. T. Oumba and W. Freundlich, Rev. Chim. Miner., 1984, 21, 311-320.

54 D. V. Navolotskaya, H. S. Toh, C. Batchelor-McAuley and R. G. Compton, ChemistryOpen, 2015, 4, 595-599.

55 J. Liu and R. H. Hurt, Environ. Sci. Technol., 2010, 44, 21692175.

56 H. D. Zucht, M. Raida, K. Adermann, H. J. Mägert and W. G. Forssmann, FEBS Lett., 1995, 372, 185-188.

57 R. V. Oppermann, G. Rölla, J. R. Johansen and S. Assev, Eur. J. Oral Sci., 1980, 88, 389-396.

58 T. N. Phan, T. Buckner, J. Sheng, J. D. Baldeck and R. E. Marquis, Oral Microbiol. Immunol., 2004, 19, 31-38.

59 M. Radzig, V. Nadtochenkoc, O. Koksharova, J. Kiwi, V. Lipasova and I. Khmel, Colloids Surf., B, 2013, 102, 300306.

60 M. A. Radtsig, O. A. Koksharova and I. A. Khmel, Mol. Genet., Mikrobiol. Virusol., 2009, 4, 27-31.

61 W. Ghandour, J. A. Hubbard, J. Deistung, M. N. Hughes and R. K. Poole, Appl. Microbiol. Biotechnol., 1988, 28, 559-565.

62 R. M. Donlan, Emerging Infect. Dis., 2002, 8, 881-890.

63 M. R. W. Brown and P. Gilbert, J. Appl. Microbiol., 1993, 74, 87S-97S.

64 A. Gupta, M. Maynes and S. Silver, Appl. Environ. Microbiol., 1998, 64, 5042-5045.

65 S. Agnihotri, S. Mukherji and S. Mukherji, Nanoscale, 2013, 5, 7328-7340.

66 A. Marguier, L. Ploux, unpublished work. 